\title{
Curcumin Loaded Eudragit S100/PLGA Nanoparticles in Treatment of Colon Cancer: Formulation, Optimization, and in-vitro Cytotoxicity Study
}

\author{
Apeksha Saraf ${ }^{1, \star}$, Nidhi Dubey ${ }^{1}$, Nitin Dubey ${ }^{2}$, Mayank Sharma ${ }^{3}$ \\ ${ }^{1}$ School of Pharmacy, Devi Ahilya Vishwavidyalaya, Takshashila Campus, Khandwa Road, Indore, Madhya Pradesh, INDIA. \\ ${ }^{2}$ College of Pharmacy, IPS Academy, AB Road, Indore, Madhya Pradesh, INDIA. \\ 3SVKM's NMIMS School of Pharmacy and Technology Management, Shirpur, Dhule, Maharashtra, INDIA.
}

\begin{abstract}
Introduction: Polymeric nanoparticles provide a promising strategy for site-specific delivery of dietary phytochemicals in the treatment of colon cancer. Curcumin (CU) is a dietary phytochemical with well-proven anti-cancer activity in colon cancer. However, its clinical application is confined because of its hydrophobicity, lack of selectivity towards tumor tissues, and poor bioavailability. Objectives: The main objective of the study was to enhance the selectivity and cytotoxicity of poorly water-soluble curcumin by fabricating polymeric nanoparticles (NPs). Methods: In the present investigation, localized delivery of $\mathrm{CU}$ to the colon was achieved by employing a combination of Eudragit S100 (ES100), as a $\mathrm{pH}$-sensitive polymer and polylactic-co-glycolic acid (PLGA), as a biodegradable polymer. The curcumin loaded dual-functional NPs were prepared by nanoprecipitation method and optimized using Box-Behnken experimental design. Results: The in-vitro cytotoxicity study of Curcumin Nanoparticles (CU-NPs) in CT26 murine colon carcinoma cells showed higher cytotoxicity in comparison to free drugs. The $\mathrm{IC}_{50}$ values of free curcumin and NPs containing curcumin was found to be $1.43 \pm 0.08 \mu \mathrm{g} / \mathrm{ml}$ and $0.25 \pm$ $0.12 \mu \mathrm{g} / \mathrm{ml}$, respectively $(p<0.05)$. Conclusion: The results of the study suggested that the dual functional polymeric NPs exhibited a remarkably promising carrier system for effective delivery of such poorly water-soluble dietary phytochemicals in colon cancer.
\end{abstract}

Key words: Colon cancer, Curcumin, Nanoparticles, Cytotoxicity, Nanoprecipitation, Box-Behnken.

\section{INTRODUCTION}

Colon cancer is the fourth leading cause of death worldwide. Conventional chemotherapy, radiation, or surgical treatments are the widely used line of treatment for cancer. However, these treatment approaches are associated with major limitations like the possibility of reoccurrence of tumors, development of resistance to chemotherapy or radiation therapy, and also they produce a large number of side effects. Therefore, it necessitates the development of an alternative modality for the prevention and treatment of cancer while overcoming the problems related to conventional chemotherapy. Besides, naturally occurring compounds are gaining substantial attention in the field of research and development due to their ability to prevent and cure various cancers. ${ }^{1-4}$ Thus, it appeared promising to search and investigate natural compounds for the treatment of cancer as they provide non-toxicity and fewer side effects in comparison to conventional chemotherapeutic agents. Curcumin (CU) is the naturally occurring polyphenol obtained from the plant Curcuma longa with potent anti-cancer activity in colon cancer. ${ }^{5-9}$ Reports from literature revealed the substantial anti-cancer activity of curcumin against various cancers by regulating several pathways involved in tumor progression, apoptosis, and cell cycle arrest. ${ }^{10-12}$ Sakuma et
Submission Date: 14-09-2020; Revision Date: 20-01-2021; Accepted Date: 24-4-2021

DOI: 10.5530/ijper.55.2s.114 Correspondence: Dr. Apeksha Saraf Assitant Professor, School of Pharmacy, Devi Ahilya Vishwavidyalaya, Takshshila Campus, Indore-452001, Madhya Pradesh, INDIA. Phone: + 91-9229246984 Email id: saraf.apeksha@ gmail.com

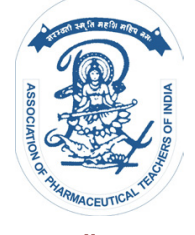

www.ijper.org 
al. (2014) reported that curcumin exerts G2/M cell cycle arrest and apoptosis through $\mathrm{Bax} / \mathrm{Bcl}-2$ and caspase $3 / 7$ expression. ${ }^{13}$ Another study also revealed curcumininduced cell cycle arrest in HCT116 colon cancer cells. The investigation showed cyclin-dependent kinase 2 (CDK2) as a main molecular target of curcumin. ${ }^{14}$ Although curcumin possesses a remarkable anti-cancer effect, but a main limiting factor for its successful delivery in the treatment of cancer are poor water solubility, poor bioavailability due to high first-pass metabolism, and low specificity towards the cancerous cell. ${ }^{15,16}$ To overcome these limitations, a nanotechnology-based colon-specific drug delivery system provides an ever-growing field in the treatment of cancer. ${ }^{17-20}$ This site-specific polymeric nanoparticulate system can achieve a high concentration of drugs in the colon while improving bioavailability and lowering systemic toxicity. ${ }^{21}$ NPs as a drug carrier system offers several advantages like (i) improved bioavailability and solubility, (ii) enhanced site-specificity of drugs, (iii) sustained drug release, and (iv) lowered systemic side effects. ${ }^{4-22}$ Several investigations on nanoformulations of curcumin revealed its efficacy in site-specific delivery to cancerous tissues. ${ }^{23-27}$ Yallapu et al. (2010) showed improved apoptosis and potential anti-cancer activity of curcumin against cell proliferation by formulating curcumin-loaded PLGA nanoparticles against metastatic cancer. ${ }^{28}$ Udompornmongkol and Chiang (2015) has demonstrated enhanced cellular uptake of curcumin in colon cancer by fabricating nanoparticles using polysaccharides viz. chitosan and gum arabic. ${ }^{17}$

A primary challenge in colon targeting is to attain maximum concentration in the colon and to prevent significant loss of drug before reaching the colon. Based on the aforementioned consideration, polymeric nanoparticles with dual function using a combination of $\mathrm{pH}$-sensitive polymer and a biodegradable polymer offers a rationale choice to deliver drugs to the colon. ${ }^{29,30}$ The $\mathrm{pH}$-sensitive polymer would facilitate the delivery of the intact drug to the colon while minimizing its loss in the upper gut whereas biodegradable polymer could provide sustained drug release. Earlier reported investigations on curcumin were mainly based on the formulation of enteric coated and micro or nanoparticles for various cancer or inflammatory bowel disease. $^{31-36}$ In our current study, nanoparticles were prepared by a combination of methacrylate polymer (ES100) and a biodegradable polymer (PLGA) to achieve high curcumin concentration locally in the colonic area. ${ }^{37}$ The curcumin loaded nanoparticles were optimized by Box-Behnken experimental design ${ }^{38,39}$ and in-vitro cytotoxicity study of nanoparticles was assessed in CT26 murine colon carcinoma cells.

\section{MATERIALS AND METHODS}

\section{Materials}

Poly (D, L-lactide-co-glycolide) (50:50) (PLGA-A, Purasorb Polymer PDLG 5002 A, Mw 17,000) was kindly provided by Corbion Purac (The Netherlands). Eudragit S100 (Mw 125,000 g/mol) was obtained from Evonik (India). Curcumin and polyvinyl alcohol (PVA) was obtained from Sigma Aldrich (St. Louis, MO, USA). CT26 cell line was procured from American Type Culture Collection (ATCC, USA) and fetal calf serum (FCS) was purchase from Biowest (USA). The cell line medium used was obtained from Hi media (Mumbai, India). 3-(4, 5-dimethylthiazol-2-yl)-2, 5-diphenyl tetrazolium bromide (MTT), propidium iodide, 4,6-diamidino-2 phenylindole (DAPI), trypsin-EDTA, and fluorescein isothiocyanate (FITC) were obtained from Sigma-Aldrich (St. Louis, MO, USA). All the other chemicals and reagents used were purchased from Sigma-Aldrich (St. Louis, MO, USA).

\section{Preparation of curcumin loaded nanoparticles}

The curcumin loaded nanoparticles were prepared by the nanoprecipitation method. ${ }^{40}$ The drug, PLGA (50:50) and ES100 were dissolved in acetone. This solution was added drop-wise into $20 \mathrm{ml}$ PVA solution under magnetic stirring for complete evaporation of the organic solvent. The nanoparticles were obtained by centrifugation at $10,000 \mathrm{rpm}(16000 \times \mathrm{g})$ for $20 \mathrm{~min}$ at $4^{\circ} \mathrm{C}$ (ELTEK, Refrigerated Centrifuge RC800 S) and the supernatant was analyzed for the free drug. The washing was carried out three times with deionized water and the suspension was freeze-dried for $48 \mathrm{hr}$ (Labcono, Model: FreeZone $4.5 \mathrm{~L}$ ) by adding $2 \%$ mannitol.

\section{Optimization of Curcumin Loaded Nanoparticles}

The optimized nanoparticles formulation was obtained by applying a 29-runs Box-Behnken experimental design (BBD) using Design-Expert ${ }^{\circledR}$ Software 11 (State-ease Inc., Trial Version). The selected independent factors were the volume of the organic phase $\left(\mathrm{X}_{1}\right)$, drug loading $\left(\mathrm{X}_{2}\right)$, the concentration of surfactant $\left(\mathrm{X}_{3}\right)$, and polymers ratio $\left(\mathrm{X}_{4}\right)$ whereas dependent variables were particle size $\left(\mathrm{Y}_{1}\right)$ and percentage drug entrapment $\left(\mathrm{Y}_{2}\right)$ as summarized in Table 1. The interaction between the variables was analyzed by polynomial equations and 3-D response surface plots generated by Design-Expert ${ }^{\mathbb{B}}$ Software 11. The polynomial equation (Eq.1) generated by Box-Behnken design is as follows:

$\mathrm{Y}=\mathrm{A}_{0}+\mathrm{A}_{1} * \mathrm{X}_{1}+\mathrm{A}_{2} * \mathrm{X}_{2}+\mathrm{A}_{3} * \mathrm{X}_{3}+\mathrm{A}_{4} * \mathrm{X}_{4}+\mathrm{A}_{5} * \mathrm{X}_{1} * \mathrm{X}_{2}$ $+\mathrm{A}_{6} * \mathrm{X}_{1} * \mathrm{X}_{3}+\mathrm{A}_{7} * \mathrm{X}_{1} * \mathrm{X}_{4}+\mathrm{A}_{8} * \mathrm{X}_{2} * \mathrm{X}_{3}+\mathrm{A}_{9} * \mathrm{X}_{2} * \mathrm{X}_{4}+$ 
$\mathrm{A}_{10} * \mathrm{X}_{3} * \mathrm{X}_{4}+\mathrm{A}_{11} * \mathrm{X}_{1}^{2}+\mathrm{A}_{12} * \mathrm{X}_{2}^{2}+\mathrm{A}_{13} * \mathrm{X}_{3}^{2}+\mathrm{A}_{14} * \mathrm{X}_{4}^{2}$ ..........Eq. 1

Where, $\mathrm{Y}$ is the response value of dependent variables, $A_{0}$ is intercept which is an arithmetic average of all of 29 runs, $A_{1}$ to $A_{14}$ are regression coefficients, $X_{1}$ to $X_{4}$ are coded values of independent variables, $\mathrm{X}_{\mathrm{a}} \mathrm{X}_{\mathrm{b}}$ (where a and $b$ are $1,2,3,4)$ are interaction terms and $X_{i}^{2}$ (where ' $i$ ' is $1,2,3,4)$ are quadratic interaction terms. The positive and negative signs to the magnitude of coefficients in polynomial equation indicate synergistic effect or antagonistic effect of the independent variable on responses. The criteria for the selection of an optimized batch was to obtain minimum particle size and maximum encapsulation efficiency.

\section{Characterization of Curcumin Loaded Nanoparticles}

\section{Fourier transform infrared (FTIR) spectra study}

To study the interaction between drug and excipients in formulated CU-NPs, FTIR spectral analysis was carried out between 4000 and $400 \mathrm{~cm}^{-1}$ (FTIR Spectrometer, Perkin Elmer), and results were compared with the spectrum of CU (free drug), PLGA, ES100, and their physical mixture.

\section{X-ray diffraction (XRD) study}

The XRD study of CU-NPs was carried out using Bruker D8 Advance X-ray diffractometer (Bruker LynxEye detector) at a wavelength of $0.154 \mathrm{~nm}$ (Cu K-alpha). The CU-NPs diffractogram was further compared with PLGA and ES100 diffractogram.

\section{Physicochemical characterization}

The shape and surface morphology of CU-NPs was determined using Field Emission Scanning Electron Microscopy (FE-SEM) (Zeiss, Germany, Model: Supra 55). The nanoparticles were coated with gold using a sputter coater while mounted on metal stubs. The resolution was set at $2 \mathrm{~nm}$ with secondary electron image display and a voltage of $2.2 \mathrm{Kv}, 20 \mathrm{mV}$ was applied. The zeta potential, particle size, and size distribution of CU-NPs were assessed by dynamic light scattering technique (Zetasizer Nano S, Malvern, UK)) at $25^{\circ} \mathrm{C}$. A homogenous suspension of nanoparticles was prepared in deionized water by sonication and was subjected to determine zeta potential, average particle size, size distribution, and polydispersity index in triplicate.

\section{Encapsulation efficiency}

The entrapment efficiency of CU-NPs was determined in triplicate by ultraviolet-visible (UV) spectrophotometric analysis. Nanoparticles (10mg) were dissolved in methanol $(10 \mathrm{ml})$ and centrifuged at $8000 \mathrm{rpm}$ for 5 min. The supernatant was filtered and analyzed for drug concentration at ambient temperature at a wavelength of $420 \mathrm{~nm}$. The percentage drug encapsulated was determined by the following equation (Eq.2):

Encapsulation efficiency $(\%)=\frac{\text { Weight of drug in nanoparticles }}{\text { Total weight of the drug }} \times 100$

\section{In-vitro drug release study}

To simulate the condition of the colon, the in-vitro drug release of CU-NPs was determined in gradual $\mathrm{pH}$ changing buffer (hydrochloric acid pH 1.2, phosphate buffer $\mathrm{pH}$ 6.8, and phosphate buffer $\mathrm{pH} 7.4) .{ }^{37}$ The NPs $(10 \mathrm{mg})$ were placed in the medium at $37 \pm 1^{\circ} \mathrm{C}$, under magnetic stirring to maintain perfect sink condition. Aliquot samples were withdrawn at an interval of $1 \mathrm{hr}$ (pH 1.2), 2 hr ( $\mathrm{pH}$ 1.2), $4 \mathrm{hr}(\mathrm{pH}$ 6.8) followed by 8 hr, $12 \mathrm{hr}, 24 \mathrm{hr}$, 48hr in $\mathrm{pH} 7.4$ while replacing with the same volume of fresh medium. The samples were centrifuged at $8000 \mathrm{rpm}$ for $5 \mathrm{~min}$ and the drug in the supernatant was measured by UV spectrophotometric analysis. The release mechanism of CU-NPs from nanoparticles was determined by fitting the drug release

\begin{tabular}{|c|c|c|c|c|c|c|}
\hline \multirow[t]{2}{*}{ Variables } & \multicolumn{6}{|c|}{ Levels } \\
\hline & & & Units & -1 (Low) & 0 (Medium) & +1 (High) \\
\hline \multirow[t]{4}{*}{$\begin{array}{c}\text { Independent } \\
\text { variables }\end{array}$} & $X_{1}$ & $\begin{array}{c}\text { Volume of organic } \\
\text { phase }\end{array}$ & $\mathrm{ml}$ & 2.5 & 5 & 7.5 \\
\hline & $X_{2}$ & Drug loading & $\%$ & 10 & 20 & 30 \\
\hline & $\mathrm{X}_{3}$ & $\begin{array}{l}\text { Concentration of } \\
\text { surfactant }\end{array}$ & $\%$ & 0.5 & 1 & 1.5 \\
\hline & $X_{4}$ & Polymers ratio & $\mathrm{mg}$ & $100: 200$ & $100: 100$ & $200: 100$ \\
\hline \multicolumn{7}{|c|}{ Constraints } \\
\hline \multirow[t]{2}{*}{ Dependent variables } & $Y_{1}$ & Particle size & $\mathrm{nm}$ & \multicolumn{3}{|c|}{ Minimize } \\
\hline & $\mathrm{Y}_{2}$ & $\begin{array}{l}\text { Drug entrapment } \\
\text { efficiency }\end{array}$ & $\%$ & \multicolumn{3}{|c|}{ Maximize } \\
\hline
\end{tabular}


data into various kinetic models viz. zero, first-order, Higuchi, Korsmeyer-Peppas, and Hixon-Crowell model.

\section{In-vitro cytotoxicity study}

The MTT assay of CU-NPs was carried out in CT26 murine colon carcinoma cells. The cells were grown in 96-well plates in RPMI 1640 with 10\% fetal calf serum (FCS) at $37^{\circ} \mathrm{C}$ and $5 \% \mathrm{CO}_{2}$. Cu-NPs and $\mathrm{CU}$ (free drug) at five different concentrations $(0.001 \mu \mathrm{g} / \mathrm{ml}, 0.01 \mu \mathrm{g} /$ $\mathrm{ml}, 0.1 \mu \mathrm{g} / \mathrm{ml}, 1 \mu \mathrm{g} / \mathrm{ml}$ and $10 \mu \mathrm{g} / \mathrm{ml}$ ) were added in cells and incubated for $24 \mathrm{hr}$. The concentration of DMSO was kept $<0.1 \%$ in all the samples. The MTT reagent was added to the cells followed by incubation for $4 \mathrm{hr}$. The dark blue formazan product formed by the cells was dissolved in DMSO under a safety cabinet and read at $550 \mathrm{~nm}$ by a plate reader (BMG Fluostar, Germany).

\section{Flow cytometric analysis}

The effect of CU-NPs on the progression of the cell cycle was determined using flow cytometry. Briefly, CT26 cells were grown in 6 well plates (10000 cells per well) in RPMI 1640 with $10 \%$ FCS and then treated with CU-NPs at a concentration of $10 \mu \mathrm{g} / \mathrm{ml}$ for 24 hr. Further, cells were gently washed with PBS and scrapped to make a single-cell suspension. The cells were fixed with methanol and followed by washing with phosphate buffer saline (PBS). Finally, cells were stained with propidium iodide and analyzed by flow cytometer (BD, FACS Calibur).

\section{Statistical analysis}

The data of in-vitro cytotoxicity studies were assessed by analysis of variance (ANOVA). The $p$-value $(<0.05)$ was considered statistically significant.

\section{Stability study}

The samples of CU-NPs formulation was evaluated for stability at refrigerated conditions $\left(2^{\circ} \mathrm{C}\right.$ to $\left.8^{\circ} \mathrm{C}\right)$ for 180 days. The samples were withdrawn and evaluated at a time interval of 30, 90, and 180 days for particle size, zeta potential, and encapsulation efficiency.

\section{RESULTS AND DISCUSSION}

\section{Optimization of Curcumin Loaded Nanoparticles by Experimental Design}

A total of 29 formulations of nanoparticles were generated by using the Design Expert ${ }^{\circledR}$ software 11 and the response variables obtained are as summarized in Table 2. The selected independent variables viz. volume of the organic phase $\left(\mathrm{X}_{1}\right)$, drug loading $\left(\mathrm{X}_{2}\right)$, the concentration of surfactant $\left(\mathrm{X}_{3}\right)$ and polymers ratio $\left(\mathrm{X}_{4}\right)$ have shown significant interactive effects on the particle size $\left(Y_{1}\right)$ and encapsulation efficiency $\left(Y_{2}\right)$. The data observed from 29 formulations were fitted to mathematical models like linear, first-order, cubic, and quadratic models using Design Expert ${ }^{\circledR}$ Software 11 to investigate the interaction between the variables. The experimental design revealed the quadratic model to be the best-fitted model for CU-NPs analysis. Threedimensional graphs and contour plots were generated and the effect of each of the responses was studied. ${ }^{41,42}$

\section{Particle size $\left(\mathrm{Y}_{1}\right)$}

The relationship between the variables was determined by analyzing quadratic parameters like transformation, fit summary, the sequential model sum of squares, lack of fit, model $\mathrm{F}$ value, $\mathrm{p}$-value, adjusted $\mathrm{R}^{2}$ and predicted $R^{2}$ (Table 3). The $p$-value $(<0.05)$ generated from ANOVA, depict that the independent variables and their interaction effects provide significant model terms in respect to response $Y_{1}$. $P$-value was less than 0.0001 for response $\mathrm{Y}_{1}$ indicating the model to be significant (Table 4). The quadratic equation (Eq. 3) generated for the $Y_{1}$ response for CU-NPs is as follows:

$\mathrm{Y}_{1}=+120.55+7.974 \mathrm{X}_{1}+1.3075 \mathrm{X}_{2}-6.13 \mathrm{X}_{3}-2.0616$ $\mathrm{X}_{4}+4.43 \mathrm{X}_{1} \mathrm{X}_{2}-3.3025 \mathrm{X}_{1} \mathrm{X}_{3}+0.835 \mathrm{X}_{1} \mathrm{X}_{4}-4.225 \mathrm{X}_{2}$ $\mathrm{X}_{3}+4.283 \mathrm{X}_{2} \mathrm{X}_{4}+17.73 \mathrm{X}_{3} \mathrm{X}_{4}+16.888 \mathrm{X}_{1}^{2}+14.42 \mathrm{X}_{2}^{2}+$ 14.689 $\mathrm{X}_{3}^{2}+22.784 \mathrm{X}_{4}^{2}$ …......Eq. 3

It is evident from the abovementioned quadratic equation that the volume of the organic phase $\left(\mathrm{X}_{1}\right)$ and drug loading $\left(\mathrm{X}_{2}\right)$ has a synergistic effect on particle size. Acetone was selected as an organic phase which is partially miscible with water to cause nanoprecipitation. The increase in the volume of acetone cause enlargement in the particle size. The increase in particle size could be attributed to the lowering of the shear force upon the addition of a high volume of organic phase in a constant volume of the aqueous phase. As the theoretical drug loading was increased from $10 \%$ to $30 \%$, the particle size gradually increased because of the increase in the amount of drug content in the CU-NPs. On the other side, an increase in the concentration of surfactant $\left(\mathrm{X}_{3}\right)$ showed a decrease in the particle size of CU-NPs. This may be due to the tendency of surfactant to form small size droplets by imparting interfacial stability to the NPs. The results showed that with an increase in concentration from the lower level (-1) to middle level $(0)$, there is a decrease in particle size but later there is no significant effect on particle size. This implies that an increase in surfactant concentration up to an optimum level reduces surface tension and consequently reduction in particle size. The increase in the ratio of the polymer has shown a negative effect on particle size. The three 


\begin{tabular}{|c|c|c|c|c|c|c|}
\hline \multirow[b]{2}{*}{$\begin{array}{c}\text { Formulation } \\
\text { Code }\end{array}$} & \multicolumn{4}{|c|}{ Independent variables } & \multicolumn{2}{|c|}{ Dependent variables } \\
\hline & $\begin{array}{l}\text { Volume of } \\
\text { organic } \\
\text { phase: } X_{1} \\
(\mathrm{ml})\end{array}$ & $\begin{array}{c}\text { Drug } \\
\text { loading: } \\
\mathrm{X}_{2} \\
(\%)\end{array}$ & $\begin{array}{c}\text { Concentration of } \\
\text { surfactant: } \\
\mathrm{X}_{3} \\
(\%)\end{array}$ & $\begin{array}{l}\text { Polymers } \\
\text { ratio: } \\
\left(X_{4}\right)\end{array}$ & $\begin{array}{c}\text { Particle size } \\
\left(Y_{1}\right) \\
(n m \pm S D)^{*}\end{array}$ & $\begin{array}{c}\text { Entrapment } \\
\text { efficiency } \\
\left(Y_{2}\right) \\
(\% \pm S D)^{*}\end{array}$ \\
\hline CU1 & 1 & 0 & 1 & 0 & $148.32 \pm 1.25$ & $61.54 \pm 0.08$ \\
\hline CU2 & -1 & 0 & 0 & -1 & $157.44 \pm 1.56$ & $45.18 \pm 0.17$ \\
\hline CU 3 & 1 & 0 & 0 & 1 & $164.69 \pm 0.92$ & $55.18 \pm 1.41$ \\
\hline CU 4 & 0 & -1 & 0 & 1 & $147.89 \pm 0.25$ & $60.65 \pm 0.07$ \\
\hline CU 5 & -1 & 0 & 0 & 1 & $151.61 \pm 2.14$ & $41.88 \pm 0.14$ \\
\hline CU 6 & 0 & -1 & -1 & 0 & $150.12 \pm 0.13$ & $58.61 \pm 0.52$ \\
\hline CU 7 & 0 & 1 & 0 & 1 & $163.73 \pm 0.67$ & $41.62 \pm 0.19$ \\
\hline CU 8 & 0 & 0 & 1 & 1 & $167.56 \pm 0.24$ & $50.39 \pm 1.33$ \\
\hline CU 9 & -1 & 0 & -1 & 0 & $147.66 \pm 1.42$ & $55.42 \pm 0.75$ \\
\hline CU 10 & 1 & -1 & 0 & 0 & $161.17 \pm 1.18$ & $59.66 \pm 2.15$ \\
\hline CU 11 & -1 & -1 & 0 & 0 & $146.61 \pm 0.28$ & $48.14 \pm 1.08$ \\
\hline CU 12 & 0 & 1 & 1 & 0 & $140.76 \pm 0.36$ & $58.74 \pm 0.15$ \\
\hline CU 13 & 0 & -1 & 0 & -1 & $158.68 \pm 1.16$ & $45.27 \pm 2.17$ \\
\hline CU 14 & 0 & 0 & 0 & 0 & $118.45 \pm 0.49$ & $62.58 \pm 0.08$ \\
\hline CU 15 & 1 & 0 & 0 & -1 & $167.18 \pm 1.4$ & $55.76 \pm 1.92$ \\
\hline CU 16 & -1 & 0 & 1 & 0 & $141.91 \pm 0.09$ & $51.82 \pm 0.18$ \\
\hline CU 17 & 0 & 0 & 0 & 0 & $122.46 \pm 0.18$ & $62.48 \pm 0.51$ \\
\hline CU 18 & 0 & 0 & -1 & 1 & $144.18 \pm 3.18$ & $50.16 \pm 1.45$ \\
\hline CU 19 & 1 & 0 & -1 & 0 & $167.28 \pm 0.15$ & $60.73 \pm 0.71$ \\
\hline CU 20 & 1 & 1 & 0 & 0 & $167.64 \pm 2.42$ & $59.15 \pm 0.09$ \\
\hline CU 21 & -1 & 1 & 0 & 0 & $135.36 \pm 0.05$ & $52.81 \pm 1.55$ \\
\hline CU 22 & 0 & -1 & 1 & 0 & $146.25 \pm 1.08$ & $56.62 \pm 0.18$ \\
\hline CU 23 & 0 & 0 & 1 & -1 & $138.09 \pm 0.65$ & $49.97 \pm 2.28$ \\
\hline CU 24 & 0 & 0 & 0 & 0 & $118.67 \pm 1.48$ & $63.08 \pm 0.78$ \\
\hline CU 25 & 0 & 0 & -1 & -1 & $185.62 \pm 0.61$ & $55.18 \pm 0.24$ \\
\hline CU 26 & 0 & 0 & 0 & 0 & $122.54 \pm 0.29$ & $62.34 \pm 1.18$ \\
\hline CU 27 & 0 & 1 & 0 & -1 & $157.39 \pm 0.47$ & $57.66 \pm 0.98$ \\
\hline CU 28 & 0 & 0 & 0 & 0 & $120.64 \pm 0.21$ & $60.51 \pm 1.37$ \\
\hline CU 29 & 0 & 1 & -1 & 0 & $161.53 \pm 0.08$ & $60.45 \pm 1.13$ \\
\hline
\end{tabular}

* Data represent $\mathrm{n}=3$, mean \pm standard deviation

dimensional graphs and contour plots for response $\mathrm{Y}_{1}$ are as shown in Figure 1.

\section{Entrapment efficiency $\left(\mathrm{Y}_{2}\right)$}

The model F-value suggests the model to be significant for response $\mathrm{Y}_{2}$ with only $0.01 \%$ chances of large F-value due to noise (Table 3). P-value was less than 0.0001 for response $\mathrm{Y}_{2}$ (Table 5). The quadratic equation (Eq. 4) generated for the $\mathrm{Y}_{2}$ response is as follows: $\mathrm{Y}_{2}=+62.198+4.731 \mathrm{X}_{1}+0.1233 \mathrm{X}_{2}-0.956 \mathrm{X}_{3}-0.7616 \mathrm{X}_{4}$ $-1.295 \mathrm{X}_{1} \mathrm{X}_{2}+1.103 \mathrm{X}_{1} \mathrm{X}_{3}+0.68 \mathrm{X}_{1} \mathrm{X}_{4}+0.07 \mathrm{X}_{2} \mathrm{X}_{3}-7.855$ $\mathrm{X}_{2} \quad \mathrm{X}_{4}+1.36 \quad \mathrm{X}_{3} \quad \mathrm{X}_{4}-4.0482 \mathrm{X}_{1}^{2}-2.534 \mathrm{X}_{2}^{2}-1.253 \mathrm{X}_{3}^{2}{ }^{2}$ $8.844 \mathrm{X}_{4}^{2}$ ….....Eq. 4
It is evident from the abovementioned quadratic equation that the volume of the organic phase $\left(\mathrm{X}_{1}\right)$ and drug loading $\left(\mathrm{X}_{2}\right)$ has a synergistic effect on response $\mathrm{Y}_{2}$. The increase in the volume of acetone from the lower level to the middle level showed an increase in encapsulation efficiency. Further, an increase in the volume of the organic phase had shown no significant increase in encapsulation efficiency. The increased volume of organic phase may prevent diffusion of drug in aqueous phase by providing a long diffusion pathway in the aqueous phase. This phenomenon reduces the drug loss and increases in particle size, which ultimately led to enhanced encapsulation efficiency. The increase in theoretical drug loading from lower (-1) to middle 
Table 3: Observed values of the quadratic parameter for particle size and encapsulation efficiency.

\begin{tabular}{|c|c|c|c|c|c|c|}
\hline Response & $\begin{array}{c}\text { Transformation } \\
\text { (maximum to } \\
\text { minimum ratio) }\end{array}$ & Adjusted $\mathbf{R}^{\mathbf{2}}$ & $\begin{array}{c}\text { Predicted } \\
\mathbf{R}^{2}\end{array}$ & $\begin{array}{c}\text { Adequate } \\
\text { precision }\end{array}$ & $\begin{array}{c}\text { Lack of fit } \\
\boldsymbol{F} \text {-value }\end{array}$ & $\begin{array}{c}\text { Model } \\
\boldsymbol{F} \text {-value }\end{array}$ \\
\hline Particle size $\left(\mathrm{Y}_{\mathbf{1}}\right)$ & 1.6 & 0.9597 & 0.8920 & 25.615 & 3.86 & 48.68 \\
\hline $\begin{array}{c}\text { Encapsulation } \\
\text { efficiency }\left(\mathrm{Y}_{\mathbf{2}}\right)\end{array}$ & 1.5 & 0.9272 & 0.8046 & 15.994 & 3.92 & 26.48 \\
\hline
\end{tabular}

\begin{tabular}{|c|c|c|c|c|c|c|}
\hline Source & Sum of Squares & df & Mean Square & $F$-value & $p$-value & \\
\hline Model & 8068.75 & 14 & 576.34 & 48.68 & $<0.0001$ & Significant \\
\hline $\begin{array}{l}\text { A-Volume of organic } \\
\text { phase }\end{array}$ & 763.05 & 1 & 763.05 & 64.45 & $<0.0001$ & \\
\hline B-Drug loading & 20.51 & 1 & 20.51 & 1.73 & 0.2092 & \\
\hline $\begin{array}{c}\text { C-Concentration of } \\
\text { surfactant }\end{array}$ & 450.19 & 1 & 450.19 & 38.02 & $<0.0001$ & \\
\hline D-Polymer ratio & 51.01 & 1 & 51.01 & 4.31 & 0.0568 & \\
\hline$A B$ & 78.50 & 1 & 78.50 & 6.63 & 0.0220 & \\
\hline $\mathrm{AC}$ & 43.63 & 1 & 43.63 & 3.68 & 0.0755 & \\
\hline$A D$ & 2.79 & 1 & 2.79 & 0.2355 & 0.6349 & \\
\hline $\mathrm{BC}$ & 71.40 & 1 & 71.40 & 6.03 & 0.0277 & \\
\hline $\mathrm{BD}$ & 73.36 & 1 & 73.36 & 6.20 & 0.0260 & \\
\hline CD & 1257.06 & 1 & 1257.06 & 106.17 & $<0.0001$ & \\
\hline$A^{2}$ & 1850.01 & 1 & 1850.01 & 156.25 & $<0.0001$ & \\
\hline $\mathrm{B}^{2}$ & 1348.90 & 1 & 1348.90 & 113.93 & $<0.0001$ & \\
\hline $\mathrm{C}^{2}$ & 1399.65 & 1 & 1399.65 & 118.21 & $<0.0001$ & \\
\hline $\mathrm{D}^{2}$ & 3368.07 & 1 & 3368.07 & 284.46 & $<0.0001$ & \\
\hline Residual & 165.76 & 14 & 11.84 & & & \\
\hline Lack of Fit & 150.20 & 10 & 15.02 & 3.86 & 0.1024 & not significan \\
\hline Pure Error & 15.56 & 4 & 3.89 & & & \\
\hline Cor Total & 8234.51 & 28 & & & & \\
\hline
\end{tabular}

level (0) showed an increase in encapsulation efficiency. A little effect of increasing drug loading further to the high level $(+1)$ on encapsulation efficiency was evident which indicated a saturation of drug loading for CU-NPs as a carrier system. On the other side, the encapsulation efficiency was found to be first increased and then decreased upon increasing the concentration of surfactant to a high level (+1). This may be associated with the fact that the addition of surfactant at optimum concentration gives a stable formulation. The stable formulation showed a small droplet size and maximum encapsulation efficiency. Further, an increase in the surfactant concentration may have favored a partition of the drug in the aqueous phase and thus, resulting in lowering of drug entrapment in CU-NPs. The encapsulation efficiency was found to decrease with an increase in polymer ratio. The three-dimensional graphs and contour plots for response $\mathrm{Y}_{2}$ are as shown in Figure 2.

\section{Optimization and validation}

From the analysis of quadratic equation, contour plots, and three-dimensional response surface graphs obtained from the Design-Expert software, it was found that volume of the organic phase, drug loading, concentration of surfactant, and polymer ratio has a significant influence on particle size and entrapment efficiency of nanoparticles. The optimized formulation of CU-NPs was selected on the criteria to attain minimum particle size and maximum encapsulation efficiency by using the numerical point prediction method of the Design Expert software ${ }^{\circledR}$. The selected optimized formulation for CU-NPs contained a $5.13 \mathrm{ml}$ volume of acetone, $20 \%$ of drug loading, $1.12 \% \mathrm{w} / \mathrm{v}$ of surfactant concentration and 1:1 drug to polymer ratio with the value of desirability of 0.984 . The experimentally obtained values of particle size $(120.58 \mathrm{~nm})$ and entrapment efficiency $(63.32 \%)$ of CU-NPs were found in agreement with 


\begin{tabular}{|c|c|c|c|c|c|c|}
\hline Source & Sum of Squares & df & Mean Square & $F$-value & $p$-value & \\
\hline Model & 1106.53 & 14 & 79.04 & 26.48 & $<0.0001$ & Significant \\
\hline A-Volume of organic phase & 268.57 & 1 & 268.57 & 89.99 & $<0.0001$ & \\
\hline B-Drug loading & 0.1825 & 1 & 0.1825 & 0.0612 & 0.8083 & \\
\hline C-Concentration of surfactant & 10.96 & 1 & 10.96 & 3.67 & 0.0759 & \\
\hline D-Polymer ratio & 6.96 & 1 & 6.96 & 2.33 & 0.1490 & \\
\hline$A B$ & 6.71 & 1 & 6.71 & 2.25 & 0.1560 & \\
\hline$A C$ & 4.86 & 1 & 4.86 & 1.63 & 0.2226 & \\
\hline$A D$ & 1.85 & 1 & 1.85 & 0.6198 & 0.4443 & \\
\hline $\mathrm{BC}$ & 0.0196 & 1 & 0.0196 & 0.0066 & 0.9366 & \\
\hline BD & 246.80 & 1 & 246.80 & 82.70 & $<0.0001$ & \\
\hline$C D$ & 7.40 & 1 & 7.40 & 2.48 & 0.1377 & \\
\hline$A^{2}$ & 106.30 & 1 & 106.30 & 35.62 & $<0.0001$ & \\
\hline$B^{2}$ & 41.66 & 1 & 41.66 & 13.96 & 0.0022 & \\
\hline$C^{2}$ & 10.19 & 1 & 10.19 & 3.41 & 0.0859 & \\
\hline$D^{2}$ & 507.40 & 1 & 507.40 & 170.01 & $<0.0001$ & \\
\hline Residual & 41.78 & 14 & 2.98 & & & \\
\hline Lack of Fit & 37.91 & 10 & 3.79 & 3.92 & 0.1002 & not significant \\
\hline Pure Error & 3.87 & 4 & 0.9682 & & & \\
\hline Cor Total & 1148.31 & 28 & & & & \\
\hline
\end{tabular}

the predicted value of particle size $(121.26 \mathrm{~nm})$ and entrapment efficiency (62.63\%) generated by Design Expert software ${ }^{\circledR} 11$.

\section{Characterization of Curcumin Loaded Nanoparticles}

\section{Fourier transforms infrared (FTIR) spectra study}

The FTIR spectra of CU-NPs showed identical characteristics bands at $2950 \mathrm{~cm}^{-1}$ (Phenolic OH stretching), $1629 \mathrm{~cm}^{-1}$ (aliphatic $\mathrm{C}=\mathrm{O}$ stretching), $1590 \mathrm{~cm}^{-1}($ aromatic $\mathrm{C}=\mathrm{C}), 1513 \mathrm{~cm}^{-1}($ aromatic $\mathrm{C}=\mathrm{O}$ stretches), and $1268 \mathrm{~cm}^{-1}(\mathrm{C}-\mathrm{O})$ with that of the spectrum of drug, polymers and their physical mixture. ${ }^{43}$ FTIR spectra of CU-NPs showed no disappearance of peaks in NPs on comparison with spectra of PLGA, ES100, and their physical mixture which depicted compatibility of the drug with all the excipients in the formulation [Figure 3].

\section{X-ray diffraction (XRD) study}

XRD data revealed an identical diffractogram showing no significant change in the state of the polymer after the formation of nanoparticles [Figure 4].

\section{Physicochemical characterization}

The optimized nanoparticles obtained by the nanoprecipitation method revealed the spherical shape and smooth surface morphology by scanning electron microscopy. The average particle size of nanoparticles was found to be $120.58 \pm 0.07 \mathrm{~nm}$. The polydispersity index and zeta potential were found to be 0.214 and $-36.92 \pm 0.22 \mathrm{mV}$, respectively [Figure 5]. The enhanced permeation and retention (EPR) effect of polymeric nanoparticles is attributed to leaky vasculature of tumor tissues and lack of lymphatic drainage. This allows easy penetration of particles within nanometer range through leaky tumors and retention of nanoparticles thereof eventually leads to the achievement of high drug concentration in the inflamed colon. Thus, as the particle size of CU-NPs was found in the nanometer range, so it can be deemed to provide an effective colon targeting. ${ }^{44}$ The PDI value indicates the polydispersity of particles in the NPs formulation. The negative zeta potential ensures the adhesion of nanoparticles to the inflamed tissues in the colonic site and contributes to the retention of nanoparticles therein. ${ }^{45}$ The encapsulation efficiency was found to be $63.32 \pm 0.42 \%$. 


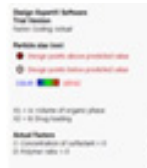

(a)
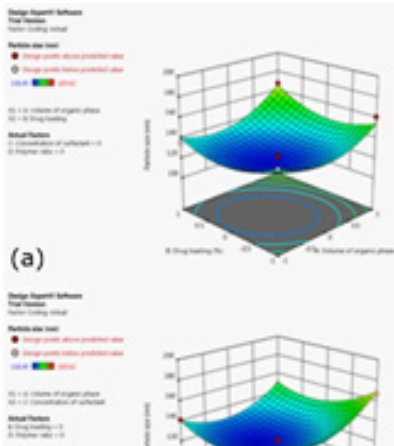

(b)
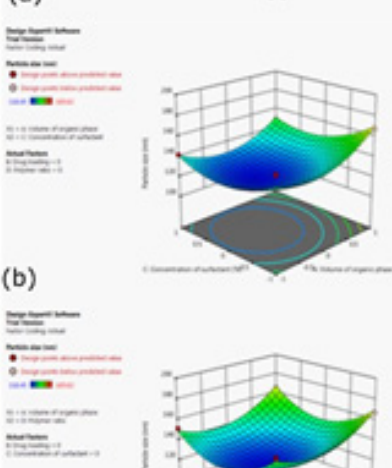

(c)
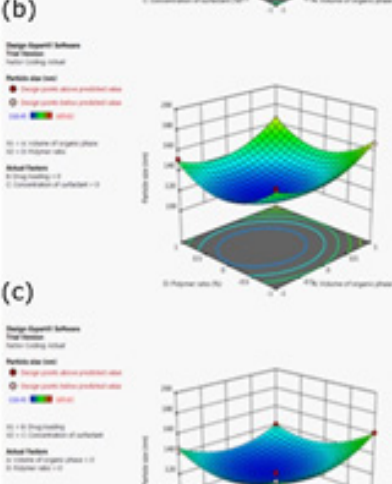

(d)

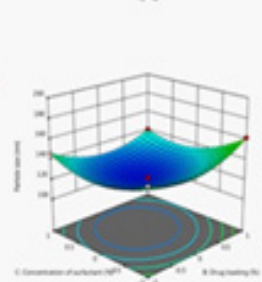

(c)

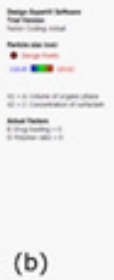

(a)
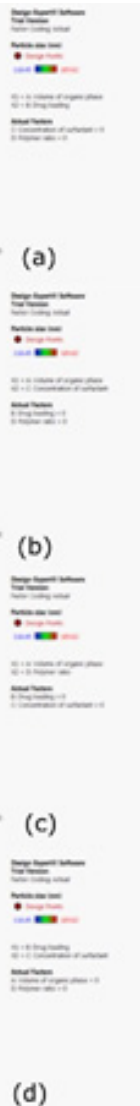

(d)

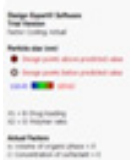

(e)
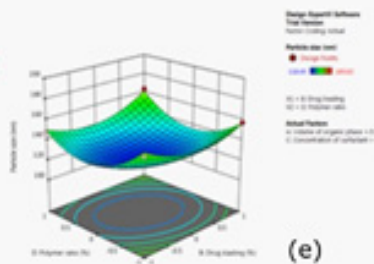

(e)

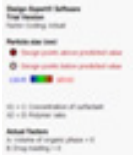

(f)
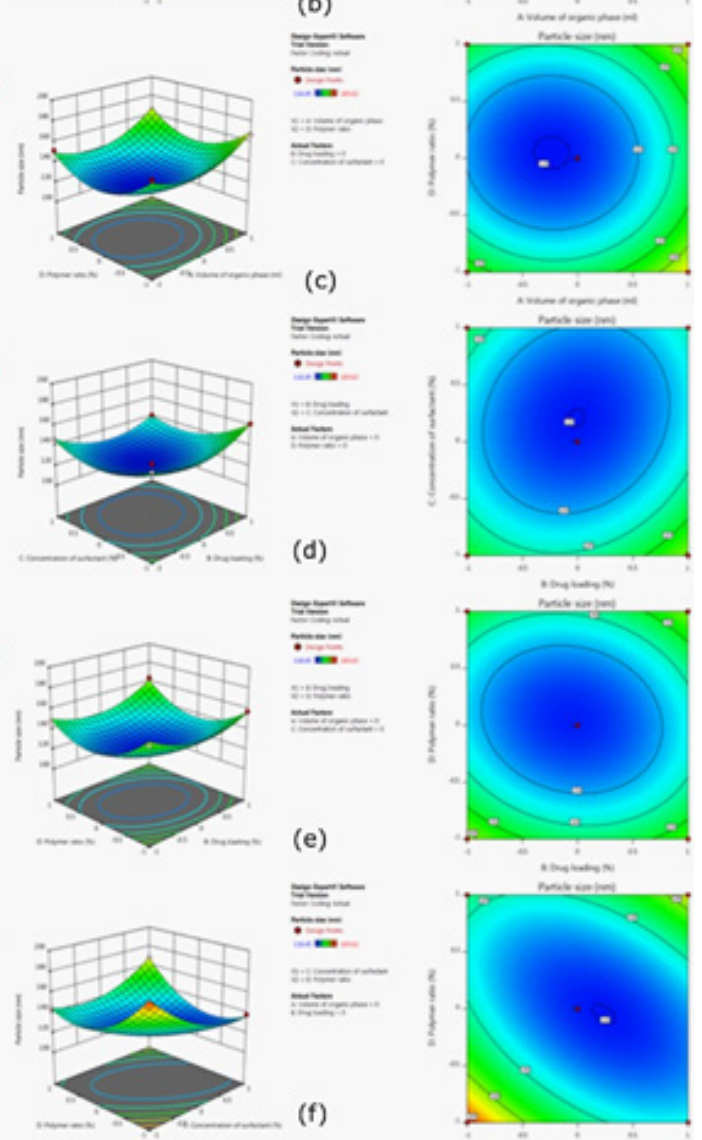
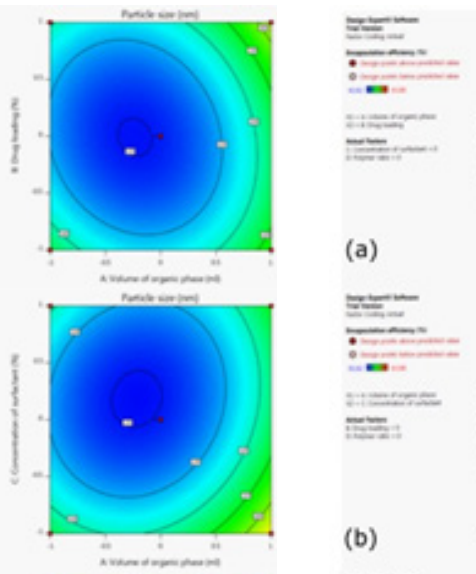

(a)

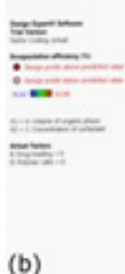

(b)
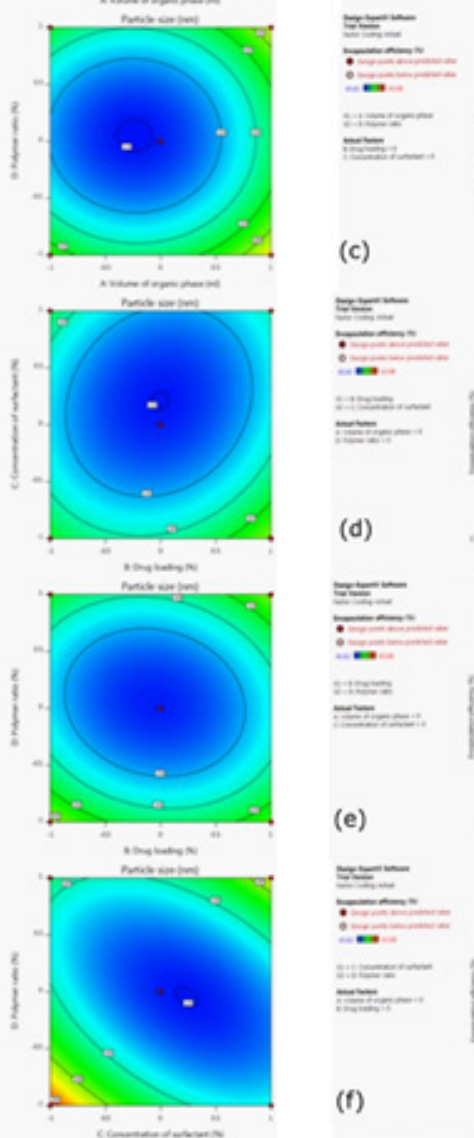

(c)

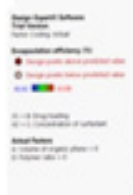

(d)

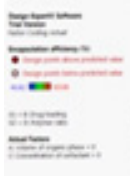

(e)

(f)

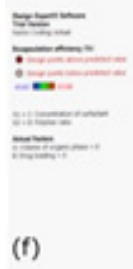

Figure 1: Three dimensional response surface plots for CU-NPs showing effect of (a) drug loading and volume of organic phase, (b) concentration of surfactant and volume of organic phase, (c) polymer ratio and volume of organic phase, (d) concentration of surfactant and drug loading, (e) polymer ratio and drug loading, and (f) polymer ratio and concentration of surfactant on particle size.

\section{In-vitro drug release study}

The in-vitro drug release from CU-NPs was studied in various $\mathrm{pH}$ range from $\mathrm{pH} 1.2$ to $\mathrm{pH} 6.8$ [Figure 6]. NPs showed negligible drug release $(<10 \%)$ at $\mathrm{pH} 1.2$ and 6.8, respectively. After attaining $\mathrm{pH} 7.4$, the drug was released from the NPs, and the percentage cumulative drug release was obtained to be $78.26 \pm 0.09$. The release
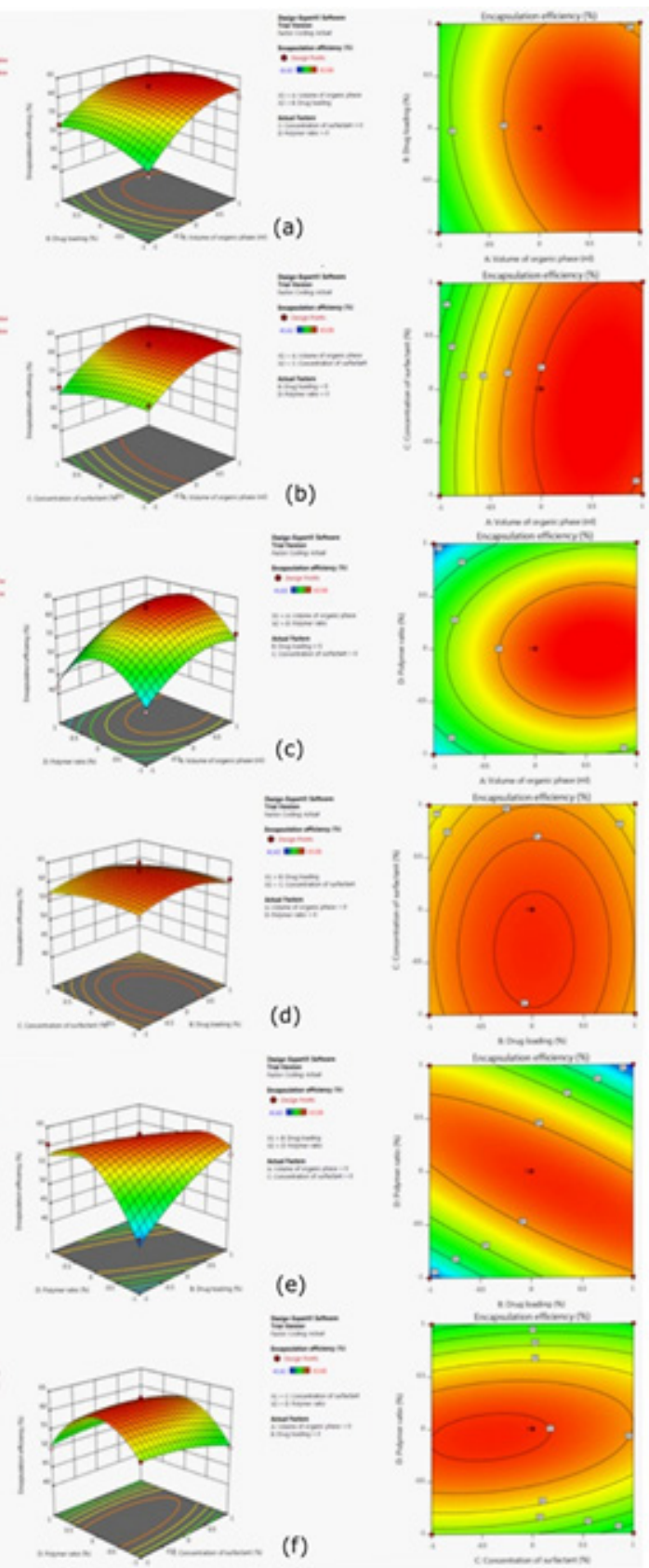

Figure 2: Three dimensional response surface plots for CU-NPs showing effect of (a) drug loading and volume of organic phase, (b) concentration of surfactant and volume of organic phase, (c) polymer ratio and volume of organic phase, (d) concentration of surfactant and drug loading, (e) polymer ratio and drug loading, and (f) polymer ratio and concentration of surfactant on encapsulation efficiency.

of curcumin from CU-NPs after attaining $\mathrm{pH}$ above 7 indicates the enteric effect of $\mathrm{pH}$-sensitive ES100 polymer and sustained drug release due to biodegradable PLGA polymer. Thus, the in-vitro data suggests the suitability of CU-NPs in achieving a high concentration of curcumin locally at the colonic site with minimal drug loss in the gastrointestinal tract. ${ }^{37}$ The release kinetic 
Table 6: Summary of data of regression coefficients of different drug release kinetic models.

\begin{tabular}{|c|c|c|c|c|c|c|}
\hline Formulation & \multicolumn{4}{|c|}{ Kinetic Models } \\
\hline & Zero-order & First-order & $\begin{array}{c}\text { Higuchi's } \\
\text { matrix }\end{array}$ & Hixson-Crowell & \multicolumn{2}{c|}{ Korsmeyer-Peppas } \\
\hline & $\mathbf{R}^{2}$ value & $\mathbf{R}^{2}$ value & $\mathbf{R}^{2}$ value & $\mathbf{R}^{2}$ value & $\mathbf{R}^{2}$ value & $\mathbf{n}$ value \\
\hline CU-NPs & 0.753 & 0.873 & 0.891 & 0.833 & 0.908 & 1.2 \\
\hline
\end{tabular}

\begin{tabular}{|c|c|c|c|c|c|}
\hline \multicolumn{2}{|c|}{ Table 7: Summary of results of stability study of CU-NPs at refrigerated conditions. } \\
\hline Temperature & Parameters & \multicolumn{4}{|c|}{ Days } \\
\hline & Particle Size $(\mathrm{nm})$ & $120.08 \pm 0.07$ & $120.16 \pm 1.24$ & $121.56 \pm 0.06$ & $122.09 \pm 0.94$ \\
\hline & $\begin{array}{c}\text { Zeta Potential } \\
(\mathrm{mV})\end{array}$ & $-36.94 \pm 0.22$ & $-35.84 \pm 0.41$ & $-35.67 \pm 0.13$ & $-35.17 \pm 0.22$ \\
\hline $\begin{array}{l}\text { Refrigerated } \\
\text { Temperature }\end{array}$ & Encapsulation Efficiency $(\%)$ & $63.32 \pm 0.15$ & $62.12 \pm 0.10$ & $61.72 \pm 0.05$ & $61.06 \pm 0.26$ \\
\hline
\end{tabular}

Data represent $n=3$, mean \pm standard deviation

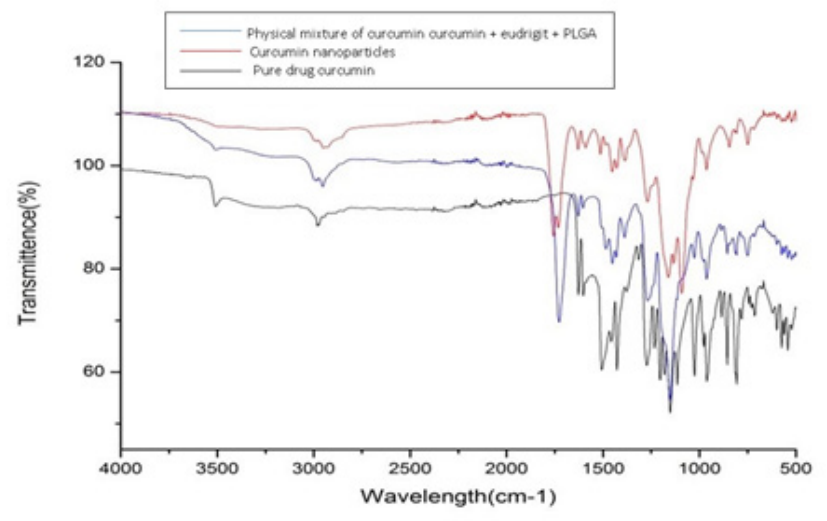

Figure 3: FTIR spectra of (a) PLGA, Eudragit S100 and physical mixture of PLGA and Eudragit, (b) CU and physical mixture of CU, PLGA and Eudragit and (c) CU-NPs and physical mixture of CU, PLGA and Eudragit.

study of CU-NPs was found to be best fitted with the Korsmeyer-Peppas model (Table 6). The value of ' $\mathrm{n}$ ' was found to be 1.2, which indicates a super case II transport mechanism wherein the drug release from CU-NPs is controlled by swelling and diffusion. ${ }^{46}$

\section{In-vitro cytotoxicity study}

The in-vitro cytotoxicity activity of CU and CU-NPs to CT26 murine carcinoma cells was assessed by MTT assay in a dose-dependent manner [Figure 7]. The CT26 cells treated with CU and CU-NPs at different concentrations exerted dose-dependent reduction in the cell viability. The drug from CU-NPs has attained higher cytotoxicity as compared to free drug. The percentage cell inhibition at $10 \mu \mathrm{g} / \mathrm{ml}$ was increased from $55.54 \%$ to $67.32 \%$ for free drug versus CU-NPs, respectively, upon $24 \mathrm{hr}$ incubation. The value of $\mathrm{IC}_{50}$ for $\mathrm{CU}$ and NPs were found to be $1.43 \pm 0.08 \mu \mathrm{g} / \mathrm{ml}$ and $0.25 \pm$
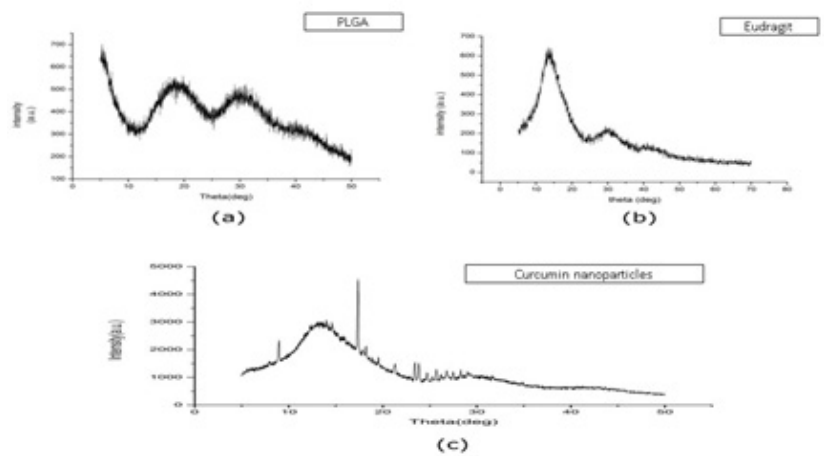

Figure 4: XRD of patterns of (a) PLGA (b) Eudragit S100 and (c) CU-NPs.

$0.12 \mu \mathrm{g} / \mathrm{ml}$, respectively $(p<0.05)$. The results showed significant cytotoxic effects of $\mathrm{CU}$ released from the fabricated NPs to a cancerous cell in the colon. Thus, the aforementioned data suggest enhanced specificity of CU from NPs towards tumors which would further contribute to improved therapeutic effects and bioavailability of hydrophobic curcumin. ${ }^{47}$

\section{Flow cytometric analysis}

CU-NPs induced cell cycle arrest in CT26 colon carcinoma cells was determined by cell cycle analysis [Figure 8]. The cell cycle arrest at various phases was evaluated by FACS Calibur flow cytometer. The result indicated the maximum cell arrest induced by $\mathrm{CU}$ released from NPs at the sub-G1 phase. The cells treated with control and CU-NPs exhibited cell cycle arrest to be 3.75 $0.94 \%$ and $20.36 \pm 2.01 \%$ in the sub-G1 phase, respectively. Thus, cell cycle arrest was significantly more in the NPs treated group than in the control group $(p<0.05) \cdot{ }^{48-50}$ 


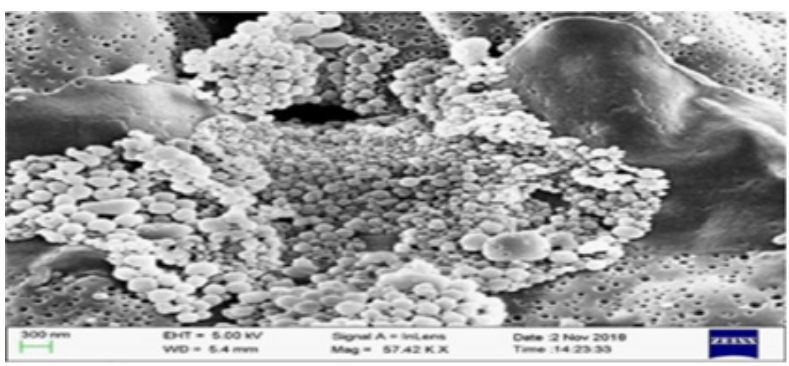

(a)

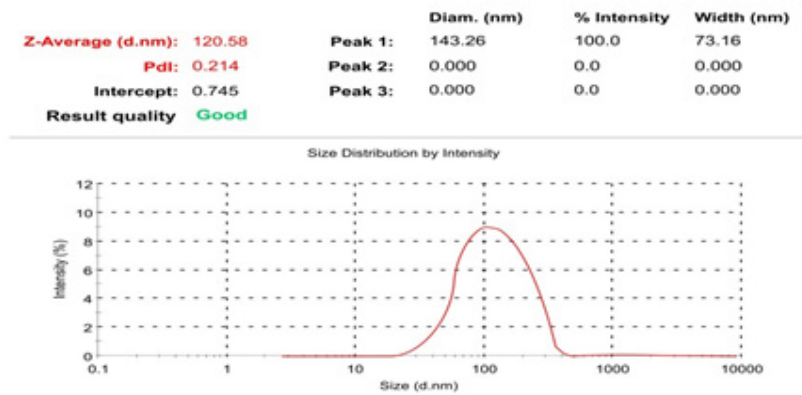

(b)

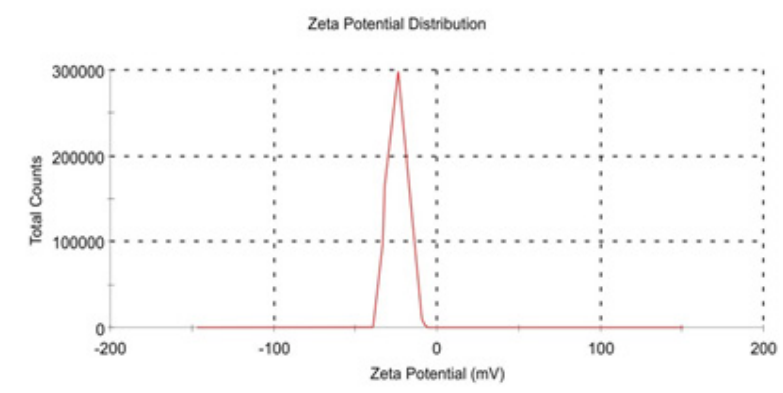

(c)

Figure 5: (a) Scanning electron microscopic image, (b) Particle size and (c) Zeta potential of CU-NPs (Data represent $\mathrm{n}=3$, mean \pm standard deviation).

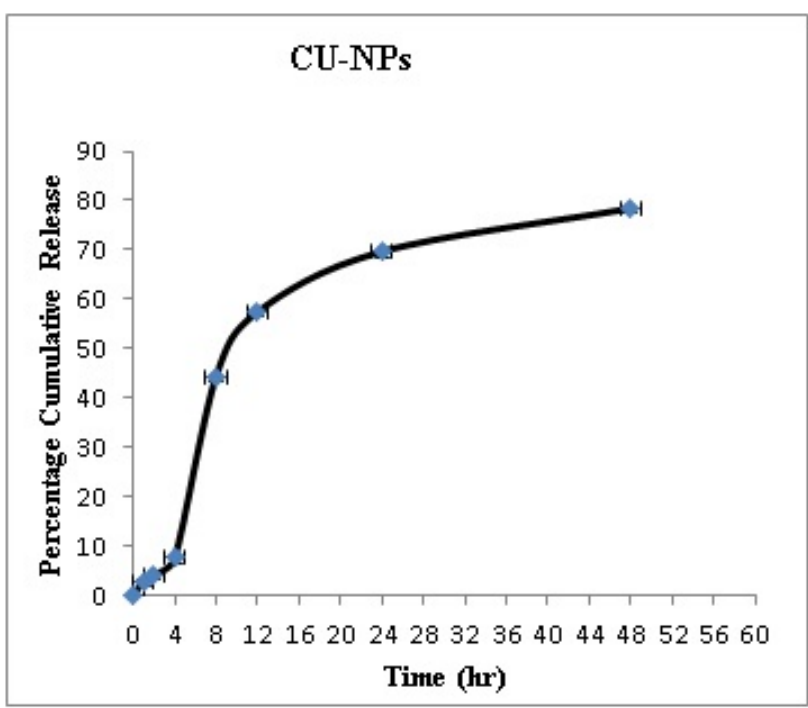

Figure 6: In-vitro drug release profile of CU-NPs in buffers of $\mathrm{pH} 1.2, \mathrm{pH} 6.8$ and $\mathrm{pH}$ 7.4. (Data represent $\mathrm{n}=3$, mean \pm standard deviation).

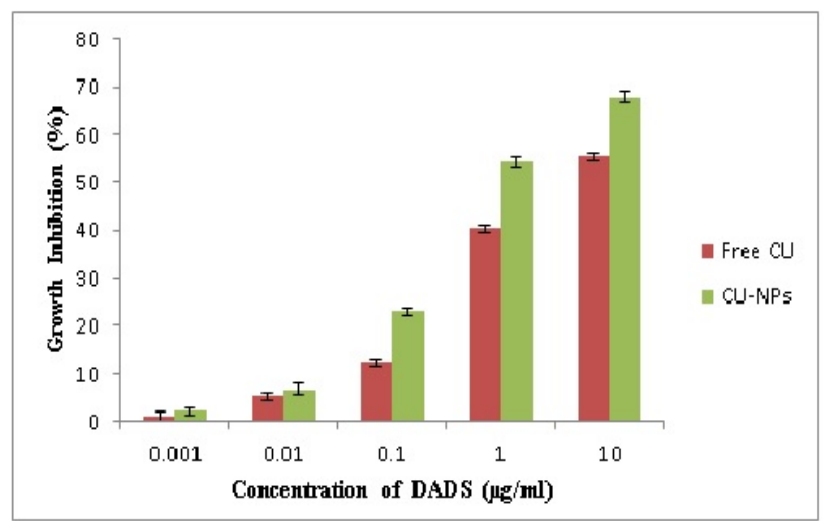

Figure 7: Percentage inhibition of СT26 cells after exposure to different concentration of free CU and CU-NPs (Data represent $n=3$, mean \pm standard deviation).

\section{(a) Control}

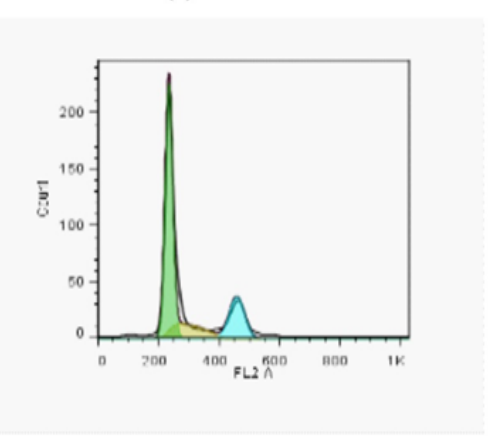

(b) Treated (CU-NPs)

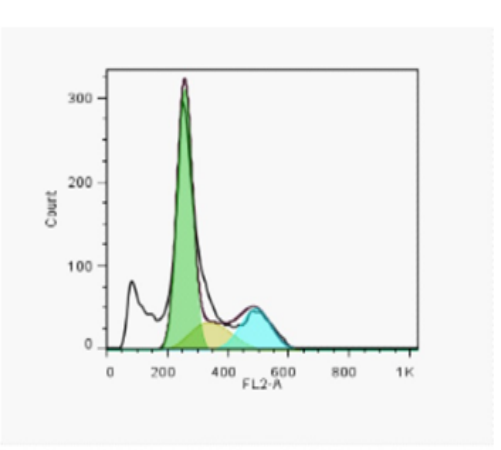

Dean-Jett-Fox
RMS $=1.25$
Freq. G1 $=57.84$
Freq. $\mathrm{S}=12.48$
Freq. G2 $=18.52$
G1 Mean $=239$
G2 Mean $=468.26$
G1 cv $=7.56$
G2 cv $=7.48$
Freq. sub-G1 $=3.75$
Freq. super-G2 $=1.68$

Dean-Jett-Fox

$\mathrm{RMS}=6.14$

Freq. $\mathrm{Gl}=42.37$

Freq. $\mathrm{S}=14.24$

Freq. $\mathrm{G} 2=16.85$

G1 Mean $=247$

$\mathrm{G} 2$ Mean $=552$

$\mathrm{G} 1 \mathrm{cv}=12.47$

$\mathrm{G} 2 \mathrm{cv}=13.95$

Freq. sub-G1 $=20.36$

Freq. super-G2 $=-0.18$
Figure 8: Histograms showing cell cycle arrest in CT26 murine colon carcinoma cells (a) control and (b) CU-NPs.

\section{Stability study}

The physicochemical properties of CU-NPs were evaluated for 180 days at refrigerated conditions $\left(2^{\circ} \mathrm{C}\right.$ to $8^{\circ} \mathrm{C}$ ) and are summarized in Table 7 . At refrigerated conditions, an insignificant change was observed in the particle size, zeta potential, and encapsulation efficiency. The results of the study suggested refrigerated conditions to be the appropriate storage condition for CU-NPs to retain their stability. ${ }^{10,51}$ 


\section{CONCLUSION}

In the present investigation, curcumin loaded NPs have shown enhanced anti-cancer activity in colon cancer as compared to free drug. The design of the experiment was found useful in the determination of the significant process variables and their influence on particle size and encapsulation efficiency of nanoparticles. The optimized CU-NPs showed desirable physicochemical properties like particle size and zeta potential for effective localized delivery of $\mathrm{CU}$ in the inflamed colon. The MTT assay exhibited dose-dependent cytotoxicity of CU-NPs towards CT26 colon carcinoma cells and cell cycle arrest at the sub-G1 stage. The CU-NPs showed a greater percentage of cell inhibition in carcinoma cells as compared to free curcumin. Hence, the results suggest that the developed dual-functional CU-NPs have the potential to be exploited for enhancement of cytotoxicity of hydrophobic phytochemicals in the treatment of colon cancer.

\section{ACKNOWLEDGEMENT}

The authors are thankful to Dr. Rajesh Sharma, Professor \& Head, School of Pharmacy, Devi Ahilya Vishwavidyalaya, Indore for his kind support, UGCDAE Consortium for Scientific Research, Indore and Sophisticated Instrumentation Centre (SIC), Indian Institute of Technology (IIT, Indore), for providing the facility at their respective organizations.

\section{CONFLICT OF INTEREST}

The authors declare no Conflict of interest.

\section{ABBREVIATIONS}

CU: Curcumin; NPs: Nanoparticles; ES100: Eudragit S100; PLGA: Polylactic-co-glycolic acid; PVA: Polyvinyl alcohol; FCS: Fetal calf serum; MTT: $\quad 3-(4, \quad$ 5-dimethylthiazol-2-yl)-2,5-diphenyl tetrazolium bromide (MTT); DAPI: propidium iodide; 4,6-diamidino-2 phenylindole; FITC: fluorescein isothiocynate; FTIR: Fourier transform infrared spectra; XRD: X-ray diffraction study; DMSO: Dimethyl sulfoxide.

\section{REFERENCES}

1. Bharali DJ, et al. Nanoparticle delivery of natural products in the prevention and treatment of cancers: current status and future prospects. Cancers. 2011;3(4):4024-45. doi:10.3390/cancers3044024.

2. Pandit RS, Gaikwad SC, Agarkar GA, Gadel AK, Rai M. Curcumin nanoparticles: Physico-chemical fabrication and it's in vitro efficacy against human pathogens. 3 Biotech. 2015;5(6):991-7. doi: 10.1007/s13205-0150302-9.
3. Hassanpour SH, Dehghani MA, Alipour SM, Karami SZ, Dehghani F. Beneficial role of curcumin in diseases treatment: A mini review. International Journal of Pharmacognosy and Chinese Medicine. 2018;2(1):000124.

4. Bansal SS, Goel M, Aqil F, Vadhanam MV, Gupta RC. Delivery systems of curcumin for cancer chemoprevention. Cancer Prevention Research. 2011;4(8):1158-71. doi: 10.1158/1940-6207.

5. Madhavi M, Madhavi K, Jithan AV. Preparation and in vitro/in vivo characterization of curcumin microspheres intended to treat colon cancer. Journal of Pharmacy and Bioallied Sciences. 2012;4(2):164-71. doi:10.4103/0975-7406.94825.

6. Tan M, Luo J, Tian Y. Delivering curcumin and gemcitabine in one nanoparticle platform for colon cancer therapy. RSC Advances. 2014;4(106):61948-59. doi: 10.1039/C4RA10431E.

7. Huang $\mathrm{Y}$, et al. Curcumin enhances the effects of irinotecan on colorectal cancer cells through the generation of reactive oxygen species and activation of the endoplasmic reticulum stress pathway. Oncotarget. 2017;8(25):4026475. doi:10.18632/oncotarget.16828.

8. Yallapu MM, Jaggi M, Chauhan SC. Curcumin Nanomedicine: A road to cancer therapeutics. Current Pharmaceutical Design. 2013;19(11):19942010. PMID: 23116309.

9. Panda AK, Chakraborty D, Sarkar I, Khan T, Sa G. New insights into therapeutic activity and anticancer properties of curcumin. Journal of Experimental Pharmacology. 2017;9:31-45. doi: 10.2147/JEP.S70568.

10. Nadafa SJ, Killedar SG. Curcumin nanocochleates: Use of design of experiments, solid state characterization, in vitro apoptosis and cytotoxicity against breast cancer MCF-7 cells. Journal of Drug Delivery Science and Technology. 2018;47:337-50. doi.org/10.1016/j.jddst.2018.06.026.

11. Anitha A, Deepa N, Chennazhi KP, Lakshmanan VK, Jayakumar R. Combinatorial anticancer effects of curcumin and 5-fluorouracil loaded thiolated chitosan nanoparticles towards colon cancer treatment. Biochimica et Biophysica Acta. 2014;1840(9):2730-43. doi: 10.1016/j. bbagen.2014.06.004.

12. Ha PT, et al. Nguyen, Preparation and anti-cancer activity of polymerencapsulated curcumin nanoparticles. Advances in Natural Sciences: Nanoscience and Nanotechnology. 2012;3(3):035002. doi:10.1088/20436262/3/3/035002.

13. Sakuma S, Maruyama C, Kohda T, Fujimoto Y. Curcumin inhibits the proliferation of a human colorectal cancer cell line Caco-2 partially by both apoptosis and G2/M cell cycle arrest. International Journal of Pharmacological Research. 2014;4(2):84-90. doi:10.7439/ijpr.

14. Lim $\mathrm{T}$, et al. Curcumin suppresses proliferation of colon cancer cells by targeting CDK2. Cancer Prevention Research. 2014;7(4):466-74. doi: 10.1158/1940-6207.CAPR-13-0387.

15. Preetha A, Kunnumakkara AB, Newman RA, Aggarwal BB. Bioavailability of curcumin: Problems and promises. Molecular Pharmaceutics. 2007;4(6):80718. doi:10.1021/mp700113r.

16. Sunny KS, et al. Molecular complexation of curcumin with $\mathrm{pH}$ sensitive cationic copolymer enhances the aqueous solubility, stability and bioavailability of curcumin. European Journal of Pharmaceutical Sciences. 2016;82:86-96. https://doi.org/10.1016/j.ejps.2015.11.010.

17. Udompornmongkol $\mathrm{P}$, Chiang $\mathrm{B}$. Curcumin-loaded polymeric nanoparticles for enhanced anti-colorectal cancer applications. Journal of Biomaterials Applications. 2015;30(5):537-46. doi: 10.1177/0885328215594479.

18. Patel VB, Patel MS, Majumdar APN. Colorectal cancer: Chemopreventive role of curcumin and resveratrol. Nutrition and Cancer. 2010;62(7):958-67. do i:10.1080/01635581.2010.510259.

19. Hamzehzadeh L, Imanparast A, Tajbakhsh A, Rezaee M, Pasdar A. New approaches to use nanoparticles for treatment of colorectal cancer: $A$ brief review. Nanomedicine Research Journal. 2016;1(2):59-68. doi: 10.7508/ nmrj.2016.02.001

20. Gulbake A, Jain A, Jain SK. Insight to drug delivery aspects for colorectal cancer. World Journal of Gastroenterology. 2016;22(2):582-99. doi:10.3748/ wjg.v22.i2.582.

21. Tran TT, Tran PH, Wang Y, Li P, Kong L. Nanoparticulate drug delivery to colorectal cancer: Formulation strategies and surface engineering. Current Pharmaceutical Design. 2016;22(19):2904-12. 
22. Cetin M, Atila A, Kadioglu Y. Formulation and in-vitro characterization of Eudragit $\circledast$ L100 and Eudragit $\circledast$ L100-PLGA nanoparticles containing Diclofenac Sodium. AAPS Pharm Sci Tech. 2010;11(3):1250-6.

23. Chaurasia S, Chaubey P, Patel RR, Kumar N, Mishra B. Curcuminpolymeric nanoparticles against colon-26 tumor-bearing mice: Cytotoxicity, pharmacokinetic and anticancer efficacy studies. Drug Development and Industrial Pharmacy. 2015;42(5):694-700.

24. Gera $M$, et al. Nanoformulations of curcumin: An emerging paradigm for improved remedial application. Oncotarget. 2017;8(39):66680-98. doi: 10.18632/oncotarget.19164.

25. Hashemi M, Ebrahimian M. Recent advances in nanoformulations for codelivery of curcumin and chemotherapeutic drugs. Nanomedicine Journal. 2017;4(1):1-7. doi: 10.22038/NMJ.2017.8046.

26. Yallapu MM, Nagesh PKB, Jaggi M, Chauhan SC. Therapeutic applications of curcumin nanoformulations. AAPS J. 2015;17(6):1341-56. doi: 10.1208/ s12248-015-9811-z.

27. Zaman MS, et al. Curcumin nanoformulation for cervical cancer treatment. Scientific Reports. 2016;6(1):20051. doi: 10.1038/srep20051.

28. Yallapu MM, Gupta BK, Jaggi M, Chauhan SC. Fabrication of curcumin encapsulated PLGAnanoparticles for improved therapeutic effects in metastatic cancer cells. Journal of Colloid and Interface Science. 2010;351(1):19-29. doi: 10.1016/j.jcis.2010.05.022.

29. Cocoa R, et al. Drug delivery to inflamed colon by nanoparticles: Comparison of different strategies. International Journal of Pharmaceutics. 2013;440(1):312. doi: 10.1016/j.ijpharm.2012.07.017.

30. Lu L, et al. Nanoparticle-based oral delivery systems for colon targeting: Principles and design strategies. Scientific Bulletin. 2016;61(9):670-81. doi. org/10.1007/s11434-016-1056-4.

31. Beloqui $\mathrm{A}$, et al. $\mathrm{pH}$-sensitive nanoparticles for colonic delivery of curcumin in inflammatory bowel disease. International Journal of Pharmaceutics. 2014;473(1-2):203-12. doi: 10.1016/j.jpharm.2014.07.009.

32. Wang Y, Li P, Peng Z, She FH, Kong LX. Microencapsulation of nanoparticles with enhanced drug loading for $\mathrm{pH}$-sensitive oral drug delivery for the treatment of colon cancer. Journal of Applied Polymer Science. 2013;129(2):714-20. doi.org/10.1002/app.38582.

33. Acharya S, Sahoo SK. PLGA nanoparticles containing various anticancer agents and tumor delivery by EPR effect. Advanced Drug Delivery Reviews. 2011;63(3):170-83. doi: 10.1016/j.addr.2010.10.008.

34. Mukerjee A, Vishwanatha JK. Formulation, characterization and evaluation of curcumin-loaded plga nanospheres for cancer therapy. Anticancer Research. 2009;29(10):3867-76. PMID: 19846921

35. Prajakta $\mathrm{D}$, et al. Curcumin loaded $\mathrm{pH}$-sensitive nanoparticles for the treatment of colon cancer. Journal of Biomedical Nanotechnology. 2009;5(5):445-55. PMID: 20201417.

36. Azandeh SS, et al. Anticancer activity of curcumin-loaded PLGA nanoparticles on PC3 prostate cancer cells. Iranian Journal of Pharmaceutical Research. 2017;16(3):868-79. PubMed PMID: 29201078.

37. Makhlof A, Tozuka Y, Takeuchi H. pH-Sensitive nanospheres for colon-specific drug delivery in experimentally induced colitis rat model. European Journal of Pharmaceutics and Biopharmaceutics. 2009;72(2):1-8. doi:10.1016/j. ejpb.2008.12.013
38. Gidwani B, Vyas A. Preparation, characterization, and optimization of altretamine-loaded solid lipid nanoparticles using Box-Behnken design and response surface methodology. Artificial Cells, Nanomedicine and Biotechnology. 2014;44(2):571-80. doi: 10.3109/21691401.2014.971462.

39. Shaikh MV, Nivsarkar M. Formulation and optimization of doxorubicin loaded polymeric nanoparticles using Box-Behnken design: Ex-vivo stability and in vitro activity. European Journal of Pharmaceutical Sciences. 2017;100:26272. doi: 10.1016/j.ejps.2017.01.026.

40. Fessi H, Puisieux F, Devissaguet J, Ammoury N, Benita S. Nanocapsule formation by interfacial polymer deposition following solvent displacement. International Journal of Pharmaceutics. 1989;55(1):R1-4. doi. org/10.1016/0378-5173(89)90281-0.

41. Singh Y, Ojha P, Srivastava M, Chourasia MK. Reinvestigating nanoprecipitation via Box-Behnken design: A systematic approach. Journal of Microencapsulation. 2015;32(1):75-85. doi:10.3109/02652048.2014.950710.

42. Sharma D, et al. Formulation and optimization of polymeric nanoparticles for intranasal delivery of lorazepam using Box-Behnken design: Invitro and in-vivo evaluation. BioMed Research International. 2014;156010. doi:10.1155/2014/156010.

43. Kumar SS, Surianarayanan M, Vijayaraghavan R, Mandal AB, MacFarlane DR. Curcumin loaded poly(2-hydroxyethyl methacrylate) nanoparticles from gelled ionic liquid in vitro cytotoxicity and anti-cancer activity in SKOV-3 cells. European Journal of Pharmaceutical Sciences. 2014;51:34-44.

44. Joshi MD, Patravale V, Prabhu R. Polymeric nanoparticles for targeted treatment in oncology: Current insights. International Journal of Nanomedicine. 2015;10:1001. doi: 10.2147/IJN.S56932.

45. Hua S, Marks E, Schneider JJ, Keely S. Advances in oral nano-delivery systems for colon targeted drug delivery in inflammatory bowel disease: Selective targeting to diseased versus healthy tissue. Nanomedicine. 2015;11(5):1117-32. doi: 10.1016/j.nano.2015.02.018.

46. Magesh B, Naidu PY, Rajarajeswari GR. S-adenosyl-I-methionine (SAMe)loaded nanochitosan particles: synthesis, characterisation and in vitro drug release studies. Journal of Experimental Nanoscience. 2009;48(12):828-43. doi.org/10.1080/17458080.2014.910616.

47. Hafeez A, Kazmi I. Dacarbazine nanoparticle topical delivery system for the treatment of melanoma. Scientific Reports. 2017;7(1):16517. doi:10.1038/ s41598-017-16878-1.

48. Sengupta A, et al. Herbicide exposure induces apoptosis, inflammation, immune modulation and suppression of cell survival mechanism in murine model. RSC Adv. 2017;7(23):13957.

49. Ebrahimnejad P, Dinarvand R, Sajadi A, Jaafari MR, Nomani AR, Azizi E, et al. Preparation and in vitro evaluation of actively targetable nanoparticles for SN-38 delivery against HT-29 cell lines. Nanomedicine. 2010;6(3):478-85. DOI: 10.1016/j.nano.2009.10.003.

50. Hu F, Liu W, Yan L, Kong F, Wei K. Optimization and characterization of poly(lactic-co-glycolic acid) nanoparticles loaded with astaxanthin and evaluation of antiphotodamage effect in vitro. Royal Society Open Science. 2019;6(10):191184. http://dx.doi.org/10.1098/rsos.191184.

51. Saraswat AL, Maher TJ. Development and optimization of stealth liposomal system for enhanced in-vitro cytotoxic effect of quercetin. Journal of Drug Delivery Science and Technology. 2020;55:101477. https://doi.org/10.1016/j. jddst.2019.101477. 


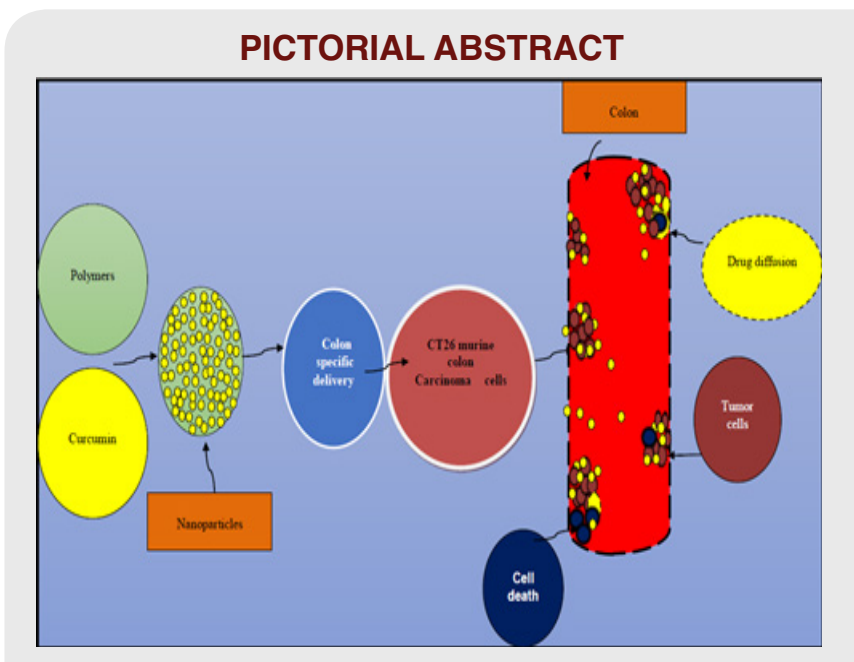

\section{SUMMARY}

NPs were fabricated with dual function containing following important features:

- An effective targeted system for delivery of poorly water soluble anti-cancer herbal drugs with enhanced cytotoxicity, stability and minimal systemic side effects,

- Prevention of drug loss in upper gastrointestinal tract and to achieve high concentration locally in colon by employing a $\mathrm{pH}$ sensitive polymer and

- An increased site-specificity of drug towards targeted cancerous cells in colon by employing biodegradable polymer.

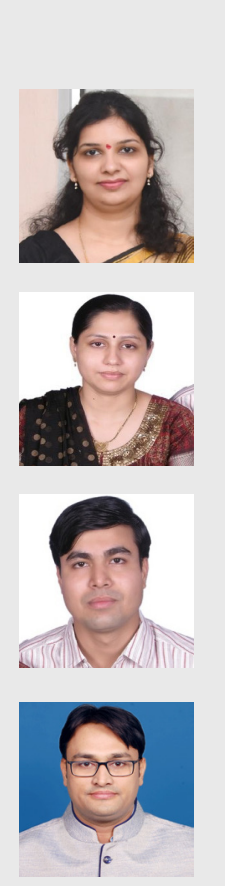

About Authors

Dr. Apeksha Saraf is currently designated as an Assistant professor at School of Pharmacy, Devi Ahilya Vishwavidyalaya, Indore. She has more than $13+$ years experience in research and academic field. Her areas of research includes novel drug delivery systems,cancer targeting, bioavailability enhancement approaches and Herbal Nanotechnology.

Dr. Nidhi Dubey is actively involved in various academic and research activities in the field of herbal drug standardization, formulation development and nanotechnology from last 14 years. She is a reviewer of many international pharmacy journals of repute and has more than 20 international/ national publications to her credit.

Dr. Nitin Dubey is actively involved in various academic and research activities in the field of analytical method development, herbal drug quality assurance and nanotechnology based drug delivery system from last 15 years. He is reviewer of many international pharmacy journals of repute and have more than 45 international/ national publications to their credit.

Dr. Mayank Sharma has $10+$ years of experience in Academia and research. He is currently designated as an Assistant Professor at SVKM's NMIMS School of Pharmacy and Technology Management, Shirpur. His areas of interest include novel drug delivery systems, Targeting RNA with small molecules, 3D Bioprinting, Enhancement of bioavailability of poorly soluble drugs.

Cite this article: Saraf A, Dubey N, Dubey N, Sharma M. Curcumin Loaded Eudragit S100/PLGA Nanoparticles in Treatment of Colon Cancer: Formulation, Optimization, and in-vitro Cytotoxicity Study. Indian J of Pharmaceutical Education and Research. 2021;55(2s):s428-s440. 